удк 342.9

DOI https://doi.org/10.32837/pyuv.v2i4(29).449

\author{
В. А. Миколаєив \\ orcid.org/0000-0001-6345-1018 \\ кандидат юридичних наук, докторант \\ Міжрегіональної Академії управління персоналом
}

\title{
ЗРАЗКОВІ ТА ТИПОВІ СПРАВИ В АДМІНІСТРАТИВНОМУ СУДОЧИНСТВІ У КОНТЕКСТІ ЄВРОПЕЙСЬКОЇ ІНТЕГРАЦІЇ УКРАЇНИ: НАПРЯМИ ЗАПОЗИЧЕННЯ
}

Вітчизняний законодавець, впроваджуючи інститути зразкових і типових справ в адміністративне судочинство, із самого початку ставив за мету підтримку загальносвітових тенденцій до спрощення судочинства. Навіть на міжнародному рівні, у т. ч. й у межах права Європейського Союзу, вже тривалий час порушуються питання реформування процесуального законодавства країн-учасниць у напрямі спрощених судових процедур як на рівні законодавства окремих країн-учасниць Європейського Союзу, так і на рівні законодавства Європейського Союзу загалом. Тому в умовах активної європеїзації різних сфер в Україні та продовження реформування української судової влади питання зразкових і типових справ в адміністративному судочинстві стали одними із тих, шляхом впровадження яких Україна здійснила спробу наблизитися до міжнародних стандартів процесуального законодавства держав-учасниць Свропейського Союзу.

В основу механізму зразкових і типових справ в адміністративному судочинстві ліг інститут пілотних рішень, які виносить Європейський суд 3 прав людини. 3 часу прийняття першого пілотного рішення застосування цього інструменту було направлено насамперед на зменшення навантаження на суди та суддів. За своєю сутністю пілотні рішення Європейського суду з прав людини є вказівками державним органам на існування системної проблеми, яка стосується великої кількості осіб, і рекомендаціями щодо усунення виявлених порушень. Шляхом впровадження інституту пілотних рішень було вирішено одразу дві задачі: по-перше, було впроваджено інститут, спрямований на вирішення багаторазово повторюваних проблем; по-друге, цей механізм сприяв вирішенню справ, що випливають зі стійкого системного неправильного функціонування адміністративних і правозастосовних органів правової системи держави. Як відзначається у науковій літературі, така процедура була впроваджена у багатьох судових системах Європи: в Угорщині, Португалії, Франції, Італії, Австрії, Словенії, Литві. Водночас існує практика, коли європейські країни відмовилися від впровадження таких процедур, наприклад, законодавці Латвії аргументували свою незгоду з таким нововведенням можливими запереченнями учасників процесу проти визна- чення справи як типової для постанови зразкового рішення; тим, що фактичні обставини по справі можуть різною мірою відрізнятися, а суд може їх врахувати як ідентичні; а також тим, що у зв'язку із запровадженням цього інституту виросте навантаження на Верховний Суд [1]. Україна у цьому контексті стала на бік держав, у яких функціонують механізми зразкових і типових справ в адміністративному судочинстві та відсутня певна єдина модель, досвід якої було запозичено Україною. Український варіант зразкових і типових справ в адміністративному судочинстві не був повністю скопійований із певної конкретної моделі та має свої особливості.

3 урахуванням того, наскільки прогресивним є запровадження механізмів зразкових і типових справ в адміністративному судочинстві, поки що кількість наукових праць, присвячених глибокому вивченню зразкових і типових справ в адміністративному судочинстві у контексті європейської інтеграції, є мінімальною. Це можна пояснити, з одного боку, новизною цих інститутів. 3 огляду на те, що їх було впроваджено лише декілька років тому, кількість відповідних наукових досліджень $є$ дуже низькою, а деякі питання, зокрема напрями запозичення зарубіжного досвіду, взагалі залишилися поза увагою дослідників. 3 іншого боку, на рівень наукової уваги до цього питання також вплинула відсутність офіційних перекладів зарубіжних законодавчих актів з адміністративної юстиції. Серед дослідників зарубіжних моделей механізму зразкових і типових справ в адміністративному судочинстві відзначимо внесок таких, як: С.В. Боднар, М.А. Бояринцева, О.Н. Ведерникова, А.В. Журавльов, В.В. Ільков, І.А. Качур, І.В. Мирончук, Л.І. Пахолок, В.Б. Пчелін, А.О. Селіванов, Т.Г. Стрілець, А.О. Черникова, B.I. Шишкін. Але водночас варто враховувати те, що праці перелічених авторів були присвячені більш загальним питанням адміністративного судочинства, які стосувалися й інститутів зразкових і типових справ. Також впровадження цих механізмів у Кодексі адміністративного судочинства України [2] не применшило актуальності наукових досліджень зарубіжних моделей, а, навпаки, надало таким дослідженням нового значення. Зарубіжний досвід функціонування механізмів зразкових і типових справ в адміністративному 
судочинстві має вивчатися і надалі з метою вдосконалення чинного законодавства, практики його застосування, продовження процесу приведення правової системи до міжнародних стандартів.

У світі існує дві моделі забезпечення єдності судової практики: континентальна й англо-американська [3, с. 187]. Незважаючи на очевидні відмінності у сутності обох моделей, їх все ж об’єднує те, що сутність кожної із них полягає у забезпеченні однакового застосування судами висновків, прийнятих у процесі діяльності судів вищих інстанцій.

У країнах англо-американської системи єдність судової практики на найвищому рівні забезпечує Верховний суд. Окрім того, як відзначається на науковому рівні, єдність судової практики також забезпечується прецедентним характером рішень суду вищого рівня. Прецеденти, покладені в основу таких рішень у конкретних справах, є обов'язковими для застосування нижчими судами при вирішенні аналогічних справ. Прецедентна система є вертикальною і передбачає обов'язок суддів дотримуватися рішень вищих судів [3, с. 187]. Щодо сутності англо-американської системи, то варто відзначити такі моменти: по-перше, судова практика має вирішальне значення для визначення змісту права та вирішальний вплив на всю правову систему; по-друге, судові прецеденти є джерелом права; по-третє, при формуванні прецедентів значна увага приділяється урахуванню правових звичаїв. Україна належить до континентальної групи держав, і саме тому практика Верховного Суду нашої держави відрізняється від діяльності аналогічних установ країн англо-американської системи.

У країнах континентальної системи завдання забезпечення єдності судової практики покладається на суд або/та касаційної інстанції або на верховні суди держав. Суд касаційної інстанції зазвичай у державі один, проте В.В. Ільков звертає увагу на те, що їх може бути декілька, у разі, коли судова система будується за принципом спеціалізації судів [3, с. 187]. Для прикладу, раніше в Україні функціонував Вищий спеціалізований суд України з розгляду цивільних і кримінальних справ, на який було покладено функції касаційної судової інстанції у відповідних спорах, втім сьогодні Верховний Суд здійснює правосуддя як суд касаційної інстанції у складі таких структурних одиниць, як: Велика Палата Верховного Суду, Касаційний адміністративний суд, Касаційний господарський суд, Касаційний кримінальний суд і Касаційний цивільний суд. Тобто Україна привела свою судову систему у відповідність до судових систем інших країн континентальної системи. Також варто враховувати, що у країнах континентальної системи верховні суді та/або суди касаційної інстанції (у разі їх існування) формулюють правові позиції у своїх рішеннях за наслідками касаційного оскарження рішень судів нижчого рівня. Висновки верховних судів та/або судів касаційної інстанції (правові позиції) $€$ умовно обов'язковими для судів нижчого рівня. Тобто, якщо суд нижчого рівня при винесенні рішення не врахує висновки Верховного Суду, цілком очевидно, що таке рішення буде скасовано [3, с. 187]. Беручи до уваги рішення у зразкових справах Верховного Суду, варто звернути увагу на те, що згідно із ч. 3 ст. 291 Кодексу адміністративного судочинства України [2] суд має враховувати правові висновки Верховного Суду, викладені у рішенні за результатами розгляду зразкової справи при ухваленні рішення у типовій справі, яка відповідає ознакам, викладеним у рішенні Верховного Суду за результатами розгляду зразкової справи. Тобто Україна також підтримала держави континентальної моделі забезпечення єдності судової практики.

Ключові відмінності, які дозволяють розрізняти держави континентальної та англо-американської моделі забезпечення єдності судової практики, у своїй праці розкриває А.В. Журавльов. Як відзначає дослідник, у сучасній доктрині та законодавстві країн континентальної Свропи домінує принцип, за яким суди у своїй діяльності керуються та підкоряються закону, а рішення, що виносяться ними, мають силу індивідуально-правових актів. Відзначається, що правовою доктриною деяких країн континентального права судова практика взагалі не розглядається як джерело права, проте деякі європейські країни пішли шляхом визнання концепції обмеженого судового прецеденту, під яким розуміється рішення вищих судових інстанцій нормативного характеру, які у процесі тлумачення закону створюють норми, що відповідають закону та підлягають обов' язковому застосуванню в подібних справах [4, с. 79]. Таким шляхом пішла й Україна, регламентувавши в нормах Кодексі адміністративного судочинства України [2] інститути зразкових і типових справ. Зразкова справа також за своєю сутністю є рішенням вищої судової інстанції нормативного характеру, яке $є$ обов'язковим для врахування при розгляді подібних справ, що у вітчизняному законодавстві дістали назву типових. А.В. Журавльов наголошує: такі рішення не варто ототожнювати з англо-американськими прецедентами, адже останні можуть бути створені одним судовим рішенням, а аналоги рішень у зразкових і типових справах в адміністративному судочинстві України є рядом судових рішень, прийнятих вищою судовою інстанцією (у випадку України - Верховним Судом, тобто не нав' язується «зверху», а виникає внаслідок сприйняття правової позиції значною частиною юридичної спільноти) [4, с. 79]. Отже, на основі вищенаведеного зробимо такі висновки щодо 
належності України до держав континентальної моделі забезпечення єдності судової практики:

по-перше, в Україні завдання забезпечення єдності судової практики покладено на Верховний Суд як найвищий орган у системі судоустрою України, який забезпечує сталість і єдність судової практики;

по-друге, Верховний Суд формулює правові позиції у зразкових рішеннях за наслідками провадження у зразковій справі, які надалі є умовно обов'язковими (правові висновки Верховного Суду мають у майбутньому обов'язково враховуватися при розгляді типових справ) для місцевих адміністративних судів;

по-третє, в Україні судова практика не є джерелом права, проте по суті в нашій державі було визнано концепцію обмеженого судового прецеденту, а рішення у зразкових і типових справах є іiї відображенням.

Отже, Україна належить до держав континентальної моделі забезпечення єдності судової практики, у яких важливе місце у забезпеченні єдності судової практики відіграє Верховний Суд. У науковій літературі до таких держав відносять Францію, Федеративну Республіку Німеччина, Угорщину, Латвію, Болгарію та ряд інших європейських держав. Засновники системи адміністративних судів в Україні брали за приклад досвід цих держав i, як наслідок, в Україні було посилено роль Верховного Суду у забезпеченні єдності судової практики шляхом наділення його повноваженнями розглядати спори про компетенцію, приймати зразкові судові рішення у спорах, що виникають 3 аналогічних підстав, у відносинах, які регулюються одними нормами права й у яких позивачами заявлено аналогічні вимоги [3, с. 169]. Тому, на нашу думку, у процесі пошуку напрямів удосконалення чинної системи зразкових і типових справ в адміністративному судочинстві варто також звертатися до досвіду таких держав.

Серед держав, які найчастіше розглядаються вітчизняними дослідниками як зразки у розбудові системи адміністративного судочинства, варто виділити Францію та Федеративну Республіку Німеччина. Розглядаючи їхній досвід у контексті правового регулювання механізмів зразкових і типових справ в адміністративному судочинстві, варто розуміти, що єдність судової практики у них забезпечується у способи, відмінні від тих, як це здійснено в Україні, а тому можливості реального використання їх досвіду у вітчизняних умовах є обмеженими.

Говорячи про Францію, варто виділити досвід цієї держави у функціонуванні інституту преюдиційних запитів. Його сутність полягає у тому, що суд, який розглядає справу по суті, зіткнувшись із проблемою застосування норми права, може зупинити провадження у справі та звернутися до найвищого судового органу з преюдиційним запитом стосовно тлумачення закону, якщо відповідне правове питання є новим, достатньо складним i виникає у багатьох справах [3, с. 188]. Переносячи цей зміст у вітчизняні реалії, можна сформулювати такий приклад. Якщо місцевий адміністративний суд розглядає типову адміністративну справу та стикається із проблемою застосування норми права, яка є новою, достатньо складною чи $є$ характерною для багатьох інших типових справ, такий суд може звернутися до вищої судової інстанції (в Україні це Верховний Суд) щодо надання висновку з цього правового питання. Отже, корисний для України досвід Франції пропонуємо розглядати передусім через призму інституту преюдиційних запитів, тим більше, що про необхідність його запровадження в нашій державі вже не перший рік ведуться дискусії, а успішність його функціонування підтверджена досвідом інших держав Свропи.

Однією з таких держав є Республіка Угорщина, найвищим судовим органом якого є Курія, зобов'язана заперечувати єдиний порядок здійснення судочинства в судах. Рішення Курії, які стосуються єдиного порядку здійснення судочинства, є обов'язковим для всіх судів. Цей орган наділено повноваженнями здійснювати правовий аналіз справ, переглядати судові рішення судів нижчих інстанцій у зв'язку з недотриманням єдності судової практики. Проте у контексті запозичення досвіду цієї держави варто звернути увагу на повноваження Курії приймати «рішення про єдність судової практики». Як відзначає В.В. Ільков, такі рішення приймаються з метою забезпечення єдності прецедентної практики. У висновку суд вказує, який закон слід забезпечувати і яким чином вирішувати справу. По суті, Курія приймає типове рішення, а суди при розгляді аналогічних справ зобов'язані враховувати ті висновки, що містяться у судовому рішенні Курії. Курія розглядає преюдиційні запити нижчих судів у випадках, коли виникають труднощі, а також наділена повноваженнями надавати нижчим судам роз'яснення законодавства [3, с. 189-190]. Всі рішення Куpiï, роз'яснення й узагальнення судової практики оприлюднюються на офіційному сайті цієї судової установи [5]. Такий механізм формування єдності й однаковості судової практики відіграє велику роль у цих державах із огляду на особливу прецедентну силу рішень цього суду. На нашу думку, запровадження процедури звернення до Верховного Суду з преюдиціальним запитом щодо надання висновку з певного правового питання могло б забезпечити такі результати: по-перше, дозволить забезпечити однакове розуміння норм права різними судами та суддями; по-друге, за допомогою інституту преюдиціального запиту питання щодо 
використання відповідних норм могли б вирішуватися ще до того, як справа надійде до Верховного Суду України, на рівні судів першої інстанції. Тобто інститут преюдиціальних запитів варто розглядати не як складову частину зразкових і типових справ, а як ще один інструмент забезпечення єдності судової практики в адміністративних справах.

Звернемо увагу на те, що спроба запровадження цього інституту вже здійснювалася вітчизняним законодавцем. Зокрема, 9 лютого 2018 р. у Верховній Раді України було зареєстровано законопроект щодо внесення змін до Кодексу адміністративного судочинства (щодо запровадження інституту преюдиційного запиту й уніфікації касаційного провадження) [6], який згодом було відкликано. Законодавцями було запропоновано удосконалення Кодексу адміністративного судочинства України [2] шляхом запровадження преюдиційного запиту й уніфікації касаційного провадження, що дозволило б забезпечити цілісність і єдність судової практики. У цьому законопроекті було врегульовано такі питання, як порядок звернення до Верховного Суду із преюдиційним запитом, розгляд Верховним Судом преюдиційного запиту, застосування судами висновку Верховного Суду на преюдиційний запит, i, на наше переконання, це було здійснено змістовно та в належній формі.

Суть процедури згідно із законопроектом полягає в такому [6]. Суди першої й апеляційної інстанції перед ухваленням рішення по справі, яку було розглянуто, приймають ухвалу про звернення до Верховного Суду із преюдиційним запитом, у якій сформульовано вимогу надати висновок щодо правильного застосування норм в адміністративній справі. Вимоги до запиту: він має бути складений у письмовій формі, має бути обгрунтованим і містити посилання на обставини, що підтверджують наявність необхідних умов для направлення до вищезазначеного суду. Також суд зазначає інформацію про правовідносини, які є предметом розгляду, а також обгрунтовує необхідність такого висновку. Відповідно, судове провадження припиняється до надання Верховним Судом висновку, а сторонам надається право подати до Верховного Суду свої пояснення.

Надійшовши до Верховного Суду, преюдиційний запит підлягає реєстрації у день надходження та не пізніше наступного дня передається судді-доповідачу для розгляду питання щодо відкриття чи відмови у відкритті провадження. Суддя-доповідач має право відмовити лише у двох випадках: по-перше, якщо Верховний Суд раніше розглядав це питання і вже видавав постанову; по-друге, якщо правильне застосування норм права є очевидним. Рішення щодо відкриття провадження приймається суддею-доповідачем само- стійно, а про відмову - постійно діючою колегією, але, якщо хоча б один суддя приймає рішення про задоволення запиту, провадження відкривається.

Після відкриття провадження справа передається на розгляд Великій Палаті Верховного Суду. У разі, якщо до Верховного Суду надійшли однотипні преюдиційні запити, суд має право об’єднати їх в одне провадження. Преюдиційний запит розглядається протягом 60 днів із дня, коли було постановлено ухвалу про відкриття преюдиційного провадження, у порядку розгляду справи судом першої інстанції у спрощеному позовному провадженні. Під час засідання суддя-доповідач доповідає про зміст запиту та позиції учасників справи, за умови, що вони подані. Під час розгляду суд може звертатися до Науково-консультативної ради по допомогу у підготовці наукового висновку щодо застосування норми права. Рішення Суду приймається у вигляді Постанови, яка набирає законної сили з моменту прийняття й оскарженню не підлягає. Рішення надсилається до першочергового суду з усіма матеріалами справи у п'ятиденний строк.

Загалом, варто зробити висновок, що інститут преюдиційного запиту є схожим на інститути типових і зразкових справ в адміністративному судочинстві, проте їх не варто ототожнювати. Вони могли б існувати як єдина система. Тому, на нашу думку, інститут преюдиційного запиту міг би стати найефективнішим напрямом впровадження у вітчизняну систему адміністративного судочинства позитивного досвіду Франції та Республіки Угорщина. У цьому контексті прийняття законопроекту № 8031 [6] могло б стати цілком доцільним шляхом його реалізації.

Окрім провідних держав Свропейського Союзу, вважаємо, що Україні варто опиратися на досвід держав, близьких історично, соціально-політично, територіально. Україна та ряд європейських держав розбудовували власні правові системи 3 ідентичних витоків, тому такий досвід буде легше запровадити у вітчизняну систему адміністративного судочинства.

Ще однією державою, досвід якої у правовому регулюванні зразкових і типових справ в адміністративному судочинстві варто було б проаналізувати, є Болгарія. Актуальність звернення до аналізу законодавства цієї держави зумовлена такими підставами. По-перше, соціалістичне минуле України та Болгарії. Остання, хоча й не була частиною Союзу Радянських Соціалістичних Республік, мала міцні відносини з цією державою, й у ній також було встановлено комуністичний режим. По-друге, 1 січня 2007 р. Болгарія вступила до Європейського Союзу, тобто реалізувала ту ціль України, яка є ключовою. По-третє, Україна та Болгарія мають схожі правові системи, що зумовлює зручність запозичення досвіду одна 
в одної. По-четверте, інститут типових справ в адміністративному судочинстві відрізняється від того, який на нинішньому етапі функціонує в Україні, а також від литовської моделі. А тому, на нашу думку, в рамках нашого дослідження доречно звернути увагу на те, якою могла би бути модель типових справ в адміністративному судочинстві в нашій державі, якби вітчизняний законодавець скористався досвідом Болгарії.

Правове регулювання типових справ в адміністративному судочинстві Болгарії здійснюється нормами Адміністративно-процесуального Кодексу Болгарії від 12 липня 2006 р. [7]. Як відзначається у науковій літературі, специфіка регулювання типових справ у цій державі зумовлена тим, що ст. 136 цього нормативно-правового акта визначено ознаки типових справ [8, с. 142]. Зміст цієї статті передбачає, шо, якщо у справі беруть участь більше 10 осіб з однаковими позовними вимогами, що не були представлені адвокатом, суд може зобов'язати їх у розумний строк призначити спільного представника. У разі, якщо такі особи не призначають адвоката, суд самостійно призначає для них представника. Якщо сторони все ж призначають свого представника, повноваження державного представника припиняються. У свою чергу, якщо сторони користуються послугами державного представника, витрати за його послуги несе адміністративний орган, у разі, якщо визнає його дії неправомірними. Із цього положення можна зробити такі висновки щодо типовості справ в адміністративному судочинстві Болгарії: по-перше, це справи, у яких 10 чи більше осіб пред'являють позовні вимоги до одного й того самого суб'єкта публічно-правових відносин; по-друге, у позивачів має бути спільний представник; по-третє, позовні вимоги усіх позивачів розглядаються як одна справа; по-четверте, у разі, якщо позивачі не доходять згоди щодо призначення спільного представника, його призначає держава, а витрати за його діяльність несе суб'єкт публічно-правових відносин у разі визнання його вини у процесі вирішення спору.

Отже, специфіка типових справ в адміністративному судочинстві Болгарії порівняно з типовими справами в адміністративному судочинстві Україні проявляється у такому:

1) в адміністративно-процесуальному законодавстві Болгарії не визначається термін «типові справи» чи синонімічні йому терміни, проте окремі адміністративні справи мають ознаки типових справ;

2) типовість справ визначається не кількістю окремих справ із тими самими відповідачами та позовними вимогами, а кількістю позивачів із однаковими позовними вимогами;

3) в адміністративно-процесуальному законодавстві Болгарії [7], на відміну від Кодексу адміністративного судочинства України [2], чітко визначено мінімальну кількість позивачів з однаковими позовними вимогами, необхідну для розгляду справи як типової;

4) у таких справах інтереси усіх позивачів мають бути представлені одним представником, обраним ними самостійно, або ж призначеним державою, якщо вони не дійшли згоди щодо його вибору.

На нашу думку, окремі моменти з болгарського досвіду могли бути використані вітчизняним законодавцем, незважаючи на те, що сутність типових справ в обох державах все ж відрізняється. Насамперед, на нашу думку, варто звернути увагу на такі моменти. Відзначимо необхідність чіткого встановлення в Кодексі адміністративного судочинства України [2] мінімальної кількості типових справ для ухвалення зразкового рішення. У Болгарії обов'язковою є наявність десяти позивачів з однаковими позовними вимогами, i, на нашу думку, така чисельність є цілком виправданою. Іншим важливим моментом є те, що усі позови з однаковими позовними вимогами до одного й того самого відповідача об’єднуються в одну справу, а інтереси усіх позивачів представляє один і той самий представник. Таке правило не має бути єдиним можливим, адже типові справи можуть розглядатися у різні проміжки часу. Але водночас у чинному законодавстві варто передбачити можливість об'єднання різних типових справ, які одночасно перебувають у провадженні одного чи різних судів, у яких позивачами звернено аналогічні позовні вимоги до того самого відповідача. Це могло б значно спростити провадження у таких справах, а також частково розвантажити суди. Більше того, у такій типовій справі може бути прийнято рішення з урахуванням висновків Верховного Суду у зразковій справі, і в такому разі розгляд таких справ буде спрощено ще більше. У такій справі може виникнути проблема із тим, який суд має розглядати подібну справу. Згідно зі ст. 25 Кодексу адміністративного судочинства України [2] «адміністративні справи з приводу оскарження індивідуальних актів, а також дій чи бездіяльності суб'єктів владних повноважень, які прийняті (вчинені, допущені) стосовно конкретної фізичної чи юридичної особи (їх об'єднань), вирішуються за вибором позивача адміністративним судом за зареєстрованим у встановленому законом порядку місцем проживання (перебування, знаходження) цієї особи-позивача або адміністративним судом за місцезнаходженням відповідача». На нашу думку, у такій «об'єднаній» справі справа має розглядатися адміністративним судом за місцезнаходженням відповідача, адже позивачі можуть проживати у різних містах, а перебування відповідача в адміністративних спорах є стабільним. 
Тому з урахуванням досвіду Болгарії пропонуємо доповнити ст. 290 Кодексу адміністративного судочинства України [2] нормою такого змісту:

«[...] Якщо у провадженні одного чи декількох судів одночасно перебувають типові справи, у яких десятьма чи більше позивачами звернено аналогічні позовні вимоги до того самого відповідача, такі справи можуть бути об'єднані в одну та розглядатися адміністративним судом за місцезнаходженням відповідача.

Об'єдання справ, у яких десятьма чи більше позивачами звернено аналогічні позовні вимоги до того самого відповідача, здійснюється за клопотанням учасника справи або за ініціативою суду [...]» .

Отже, серед напрямів запозичення досвіду європейських держав у правовому регулюванні зразкових і типових справ в адміністративному судочинстві нами виділено:

- впровадження інституту преюдиційного запиту;

- визначення мінімальної кількості типових адміністративних справ, необхідних для відкриття провадження у зразковій справі;

- впровадження можливості оскарження ухвали суду про призупинення розгляду типової справи для її розгляду у порядку зразкової;

- регламентацію розгляду типової справи, яка відповідає ознакам, викладеним у рішенні Верховного Суду за результатами розгляду зразкової справи, у порядку спрощеного позовного провадження;

- визначення можливості об'єднання кількох типових адміністративних справ в одну, якщо у провадженні одного чи декількох судів одночасно перебувають типові справи, у яких десятьма чи більше позивачами звернено аналогічні позовні вимоги до того самого відповідача.

\section{Jimepamypa}

1. Стрілець Т.Г. Судова реформа: навіщо потрібні типові і зразкові справи. Судово-юридична газета. URL: https: sud.ua/uk/news/laws/109238-sudebnayareforma-zachem-nuzhny-tipichnye-i-obraztsovye-dela (дата звернення: 29.12.2019).

2. Кодекс адміністративного судочинства України : Закон України від 06 липня 2005 р. № 2747-IV. Відомості Верховної Ради України. 2005. № 35, 35-36, 37. С. 1358. Ст. 446.

3. Ільков В.В. Джерела права в адміністративному судочинстві України : дис. ... докт. юрид. наук : 12.00.07 ; Харківський національний університет внутрішніх справ Міністерство внутрішніх справ України, Дніпропетровський державний університет внутрішніх справ Міністерство внутрішніх справ України. Дніпро, 2017. $478 \mathrm{c.}$

4. Журавльов А.В. Судовий прецедент як джерело права в адміністративному судочинстві. Актуальні проблеми держави і права. 2016. Вип. 76. С. 75-84.

5. Офіційний сайт Курії Республіки Угорщина. URL: hu/hu/elvdont/112017-szamu-kozigazgatasi-elvidontes (дата звернення: 20.06.2016).
6. Про внесення змін до Кодексу адміністративного судочинства України (щодо запровадження інституту преюдиційного запиту та уніфікації касаційного провадження) : Проект Закону України від 09 лютого 2018 р. № 8031. URL: http: w1.c1.rada.gov.ua/pls/ zweb2/webproc4_1?pf3511=63468 (дата звернення: 29.12.2019).

7. Административнопроцесуален кодекс. В сила от 12.07.2006 г. URL: https: lex.bg/laws/ ldoc/2135521015 (дата звернення: 29.12.2009).

8. Качур I.А. Інститут адміністративної справи в адміністративному судочинстві України : дис. ... канд. юрид. наук : 12.00.07 / Київський міжнародний університет, Державний науково-дослідний інститут Міністерства внутрішніх справ України. Київ, 2018. 225 с.

\section{Анотація}

Миколаєиь В. А. Зразкові та типові справи в адміністративному судочинстві в контексті європейської інтеграції України: напрями запозичення. - Стаття.

У статті проаналізовано специфіку правового регулювання зразкових і типових справ в адміністративному судочинстві за кордоном. Досліджено особливості зразкових і типових справ в адміністративному судочинстві у Франції, Угорщині та Болгарії. Виведено по кожній країні перелік основних ознак відповідного типу справ або справ, наближених до тих, що встановлені у національному адміністративному законодавстві. Виокремлено перелік позитивних i негативних аспектів правового регулювання зразкових і типових справ в адміністративному судочинстві кожної з європейських держав. Деталізовано зміст i значення кожного аспекту. Сформульовано напрями запозичення позитивного зарубіжного досвіду у національне адміністративне законодавство. Наведено чіткі законодавчі пропозиції з метою оптимізації відповідної сфери адміністративно-правового регулювання. На міжнародному рівні, у т. ч. й у межах права Європейського Союзу, вже тривалий час порушуються питання реформування процесуального законодавства країн-учасниць у напрямі спрощених судових процедур як на рівні законодавства окремих країн-учасниць Європейського Союзу, так і на рівні законодавства Європейського Союзу загалом. Тому в умовах активної європеїзації різних сфер в Україні та продовження реформування української судової влади питання зразкових і типових справ в адміністративному судочинстві стали надзвичайно актуальними. Крім того, ураховуючи те, наскільки прогресивним є запровадження механізмів зразкових і типових справ в адміністративному судочинстві, поки що кількість наукових праць, присвячених їх глибокому вивченню в адміністративному судочинстві у контексті європейської інтеграції, є мінімальною.

Ключові слова: зразкові справи, типові справи, адміністративне судочинство, європейська інтеграція, адміністративне законодавство.

\section{Summary}

Nikolayets $V$. A. Model and typical cases in administrative justice in the context of European integration of Ukraine: directions for borrowing. Article.

In the article the specifics of the legal regulation of model and typical cases in administrative proceedings abroad are analyzed. The peculiarities of model and typical cases in administrative proceedings in France, Hungary and Bulgaria are investigated. Listed for each country is a list of the main features of the relevant 
type of cases or cases, similar to those established in national administrative legislation. The list of positive and negative aspects of the legal regulation of model and typical cases in the administrative proceedings of each of the European states is highlighted. The content and meaning of each aspect are detailed. The directions of borrowing positive foreign experience in the national administrative legislation are formulated. Clear legislative proposals are presented to optimize the relevant area of administrative and legal regulation. At the international level, including within the framework of European Union law, the issues of reforming the procedural law of the member states in the direction of simplified litigation have been raised for a long time, both at the level of the legislation of the individual member states of the European Union and at the level of the legislation of the European Union as a whole. Therefore, in the context of active Europeanization of various spheres in Ukraine and continued reform of the Ukrainian judiciary, the issues of model and typical cases in administrative justice became extremely relevant. Moreover, given how progressive the introduction of exemplary and model cases in administrative justice is, the number of scientific papers devoted to the deep study of exemplary and model cases in administrative justice in the context of European integration is minimal.

Key words: model cases, standard cases, administrative justice, European integration, administrative law. 